Educational Research: The Attraction of Psychology 


\title{
Educational Research
}

\section{VOLUME 6}

\begin{abstract}
Aims \& Scope
Freedom of inquiry in educational research can no longer be taken for granted. Narrow definitions of what constitutes 'scientific' research, funding criteria that enforce particular research methods, and policy decision processes that ignore any research that is not narrowly utilitarian, in many countries, create a context that discourages scholarship of a more speculative, exploratory, or critical sort.

In this series, internationally leading scholars in philosophy and history of education engage in discourse that is sophisticated and nuanced for understanding contemporary debates. Thus social research, and therefore educational research, is again focused on the distinctive nature of what it studies: a social activity where questions of meaning and value must be addressed, and where interpretation and judgment play a crucial role.

This educational research takes into account the historical and cultural context and brings clarity to what actually constitutes science in this area. The timely issues that are addressed in this series bear witness to the belief that educational theory cannot help but go beyond a limited conception of empirical educational research to provide a real understanding of education as a human practice. They surpass the rather simple cause-and effect rhetoric and thus transgress the picture of performativity that currently keeps much of the talk about education captive. The authors are united in the belief that 'there is a place within the social sciences in general', and within the discipline of education in particular, for 'foundational' approaches that enable the systematic study of educational practice from a discipline-orientated approach.
\end{abstract}

For further volumes:

http://www.springer.com/series/8398 
Paul Smeyers - Marc Depaepe

Editors

\section{Educational Research: \\ The Attraction of Psychology}

Springer 


\section{Editors}

Paul Smeyers

Ghent University and Katholieke Universiteit Leuven, Belgium

\author{
Marc Depaepe \\ Campus Kortrijk, Subfaculteit Psychologie \\ en Pedagogische Katholieke Universiteit \\ Leuven, Belgium
}

ISBN 978-94-007-5037-1

ISBN 978-94-007-5038-8 (eBook)

DOI 10.1007/978-94-007-5038-8

Springer Dordrecht Heidelberg New York London

\author{
Library of Congress Control Number: 2012949848
}

(C) Springer Science+Business Media Dordrecht 2013

This work is subject to copyright. All rights are reserved by the Publisher, whether the whole or part of the material is concerned, specifically the rights of translation, reprinting, reuse of illustrations, recitation, broadcasting, reproduction on microfilms or in any other physical way, and transmission or information storage and retrieval, electronic adaptation, computer software, or by similar or dissimilar methodology now known or hereafter developed. Exempted from this legal reservation are brief excerpts in connection with reviews or scholarly analysis or material supplied specifically for the purpose of being entered and executed on a computer system, for exclusive use by the purchaser of the work. Duplication of this publication or parts thereof is permitted only under the provisions of the Copyright Law of the Publisher's location, in its current version, and permission for use must always be obtained from Springer. Permissions for use may be obtained through RightsLink at the Copyright Clearance Center. Violations are liable to prosecution under the respective Copyright Law.

The use of general descriptive names, registered names, trademarks, service marks, etc. in this publication does not imply, even in the absence of a specific statement, that such names are exempt from the relevant protective laws and regulations and therefore free for general use.

While the advice and information in this book are believed to be true and accurate at the date of publication, neither the authors nor the editors nor the publisher can accept any legal responsibility for any errors or omissions that may be made. The publisher makes no warranty, express or implied, with respect to the material contained herein.

Printed on acid-free paper

Springer is part of Springer Science+Business Media (www.springer.com) 


\section{Earlier Volumes in this Series}

Educational Research: Why 'What Works' Doesn't Work

Paul Smeyers and Marc Depaepe

2006, VI, 195 p., Hardcover

ISBN 978-1-4020-5307-8

Educational Research: Networks and Technologies

Paul Smeyers and Marc Depaepe

2007, VI, 228 p., Hardcover

ISBN 978-1-4020-6612-2

Educational Research: the Educationalization of Social Problems Paul Smeyers and Marc Depaepe

2008, VI, 247 p., Hardcover

ISBN 978-1-4020-9722-5

Educational Research: Proofs, Arguments, and Other Reasonings Paul Smeyers and Marc Depaepe

2009, VI, 199 p., Hardcover

ISBN 978-90-481-3248-5

Educational Research: The Ethics and Aesthetics of Statistics

Paul Smeyers and Marc Depaepe

2010, VIII, 224 p., Hardcover

ISBN 978-90-481-9872-6 